cal Involvement in the Later Years: A Longitudinal Survey." American Journal of Political Science 32:302-16. —_ and Richard G. Niemi. 1968. "The Transmission of Political Values from Parent to Child." American Political Science Review 63:169-84.

_, and Richard G. Niemi. 1969. "IntraParty Communication and the Selection of Delegates to a National Convention." Western Political Quarterly 22:29-46.

-, and Richard G. Niemi. 1971. "The Division of Political Labor Between Mothers and Fathers." American Political Science Review 65:69-82.

- and Richard G. Niemi. 1974. The Political Character of Adolescence: The Influence of Families and Schools. Princeton: Princeton University Press.

, and Richard G. Niemi. 1975. "Continuity and Change in Political Orientations: A Longitudinal Study of Two Generations." American Political Science Review 69:1316-35.

-, and Richard G. Niemi. 1978. "The Persistence of Political Orientations: An Overtime Analysis of Two Generations." British Journal of Political Science 8:33363.
—_ and Richard G. Niemi. 1981. Generations and Politics: $A$ Panel Study of Young Adults and Their Parents. Princeton: Princeton University Press. , and Laura Stoker. 1995. "Life-Cycle Transitions and Political Participation: The Case of Marriage." American Political Science Review 89:421-36.

, and Normal Thomas. 1968. "Men and Women in Party Elites: Social Roles and Political Resources." Midwest Journal of Political Science 12:469-92.

__ Jan Van Deth, et al. 1989. Continuities in Political Action: A Longitudinal Study of Political Orientations in Three Western Democracies. Berlin: Walter de Gruyter.

$\longrightarrow$, and L. Harmon Zeigler. 1971. "Response Styles and Politics: The Case of School Boards." Midwest Joumal of Political Science 15:290-321.

Kilpatrick, Franklin P., Milton C. Cummings, Jr., and M. Kent Jennings. 1964a. The Image of the Federal Service. Washington, DC: The Brookings Institution.

- 1964b. Source Book of a Study of Occupational Values and the Image of the Federal Service. Washington, DC: The Brookings Institution.
Miller, Warren E., and M. Kent Jennings. 1986. Parties in Transition: A Longitudinal Study of Party Leaders and Followers. New York: Russell Sage.

Niemi, Richard G., and M. Kent Jennings. 1991. "Issues and Inheritance in the Formation of Party Identifications." American Journal of Political Science 35:970-88.

Percheron, Annick, and M. Kent Jennings. 1981. "Political Continuities in French Families: A New Perspective On an Old Controversy." Comparative Politics 13:42136.

Zeigler, L. Harmon, and M. Kent Jennings. 1974. Governing American Schools: Political Interaction in Local School Districts. North Scituate, MA: Duxbury Press.

\section{About the Author}

Paul Allen Beck is chair and professor of political science at The Onio State University. $\mathrm{He}$ is author of works on voting behaviour, political socialization, and political participation.

\title{
Report of the Executive Director
}

\author{
Catherine E. Rudder, American Political Science Association
}

\section{Highlights}

Few organizations are blessed with the quality of leadership and participation that APSA members willingly offer to this scholarly society. From the creativity of President Elinor Ostrom to the conscientiousness of an anonymous reviewer of an $A P S R$ or $P S$ manuscript, members are served in thousands of ways each year by each other. Our job in the national office is to help orchestrate all the activities of this Association. We suggest, we facilitate, we represent, we implement, and we serve. Ultimately, the strength of our cooperative society rests on all of us who are improving existing programs and creating new ones.

Consider, for example, some of the achievements of this past year. Together, the Association's members, committees, officers, and staff have:

- Established a Civic Education Task Force, under President Ostrom's leadership, to address the need to teach students the theory and skills of civic involvement, and held a two-day retreat to plan the group's activities.

- Hosted delegations of Eastern European scholars and teachers from Russia, Latvia, Poland, Bosnia, Hungary, and the Czech Republic for programs at the national office on civic education.

- Extended the German participation in the Congressional Fellowship Program, thanks to a stellar review from and the generosity of the German Marshall Fund.

- Established a journal donation program for Sub-Saharan African universities upon the end of the AAAS-ACLS journals program, adding to our ongoing contributions to Eastern and Central Europe.

- Concluded an agreement with the Political Science Association of the United Kingdom to engage in joint projects, the first of which will be the inclusion of British institutions in next year's Guide to Graduate Faculty and Programs.
- Instituted the Frank J. Goodnow Award to recognize contributions to the discipline and Association.

- Conducted focus groups of APSA members on the planned Centennial Campaign to celebrate the discipline's first 100 years by investing in the next 100 .

- Recruited the leadership for the Campaign, and organized the Executive Committee and President's Council of the Campaign.

- Expanded by one-third the Small Research Grants Program to include projects on the evolution of the discipline and profession.

- Established a Higher Education Advisory Group composed of senior academic administrators to advise APSA on higher education issues and to assist APSA in our representational activities.

- Created a pilot on-line archive of Annual Meeting papers.

- Expanded APSA's Web site to include a searchable index of $A P S R$ articles and the Annual Meeting Program; set up an interactive fea- 
ture so that members can renew membership and preregister for the Annual Meeting electronically; and explored other ways APSA can take advantage of the new digital environment.

- Prepared in-house and published several new publications, including the triennial Directory of Members, the newly revised Getting Published in Political Science Journals: A Guide for Authors, Editors and $\mathrm{Li}$ brarians compiled by Fenton Martin and Robert Goehlert of Indiana University, the new Directory of Women of Color in Political Science, the annual Directory of Departments of Political Science, and, for the first time in 13 years, a Directory of Congressional Fellowship Alumni.

- Conducted six different surveys to produce data and reports for the Departmental Services Program, the placement report, the Committee on Professional Ethics, and the Minority Identification Project.

- Received three grants from the $\mathrm{Na}$ tional Science Foundation to fund the Ralph Bunche Summer Institute for three years, to help scholars attend the World Congress of the International Political Science Association, and to conduct a survey on job placement among newly-minted Ph.D.s and ABDs in political science.

- Instituted a new spring round for the Minority Identification Project in order to encourage more students to enroll in doctoral programs and added an additional fellowship for Latinos to the APSA Graduate Fellowship Program.

- Broadened language on equal opportunity in the Professional Ethics Guide, which had referred exclusively to hiring practices, to include any conditions of employment and incorporated an explicit statement about discrimination on the basis of sexual orientation.

- Reviewed, cleaned out, and moved the APSA Archive to Mount Vernon College of George Washington University and dedicated the archive to Walter E. Beach.

- Made needed changes at APSA headquarters, including renovating APSA's building, networking its computers, and implementing AP-
SA's strategic plans for programs and for digital processing.

- Revamped submission of Annual Meeting proposals and centralized the processing in the national office in order to lessen the load on the Program Committee and to rationalize the process for members.

- Assisted a record 50 international scholars and graduate students in attending the Annual Meeting, as well as an additional 24 travel grants for U.S. graduate and Ralph Bunche students.

All of these activities, which represent only a sampling of our accomplishments, were carried on in partnership between the national office and some segment of the Association-from the Committee on Professional Ethics to the Women's Caucus for Political Science-or between APSA and other institutions like the Harvard University Library (Annual Meeting Papers On-Line) and $\mathrm{H}-\mathrm{Net}$ at Michigan State University. All have been led by dedicated APSA members, like William J. Ball of the College of New Jersey, Paula McClain of the University of Virginia, Sidney Verba of Harvard, and Kenneth Janda of Northwestern University. Literally hundreds of people have been involved in creating, overseeing, and carrying out these projects, as well as our myriad of other ongoing programs reported to you in the remainder of this report and in the pages of $P S$ over the past year.

\section{Annual Meeting}

Jennifer Hochschild of Princeton University and Ronald Rogowski of University of California-Los Angeles presided over our $92^{\text {nd }}$ Annual Meeting with inordinate skill, leading a Program Committee of 46 division chairs who, with related groups, assembled a record 650 panels in San Francisco. Attendance also exceeded all previous APSA meetings with 6,055 registered scholars, exhibitors, and members of the press ( $\mathrm{Ta}$ ble 1).

The 1996 meeting, under the theme of "Inequality and Politics," was characterized by several successful innovations in programming in-

\begin{tabular}{ll} 
TABLE 1 & \\
Annual Meeting \\
Registration, 1968-96 \\
\hline 1968 & 3723 (Washington, D.C.) \\
1969 & 4142 (New York) \\
1970 & 2397 (Los Angeles) \\
1971 & 2732 (Chicago) \\
1972 & 3380 (Washington, D.C.) \\
1973 & 2312 (New Orleans) \\
1974 & 2773 (Chicago) \\
1975 & 2478 (San Francisco) \\
1976 & 2295 (Chicago) \\
1977 & 2624 (Washington, D.C.) \\
1978 & 2373 (New York) \\
1979 & 2687 (Washington, D.C.) \\
1980 & 2745 (Washington, D.C.) \\
1981 & 2887 (New York) \\
1982 & 2205 (Denver) \\
1983 & 2859 (Chicago) \\
1984 & 3391 (Washington, D.C.) \\
1985 & 2842 (New Orleans) \\
1986 & 3602 (Washington, D.C.) \\
1987 & 3524 (Chicago) \\
1988 & 4161 (Washington, D.C.) \\
1989 & 3496 (Atlanta) \\
1990 & 4505 (San Francisco) \\
1991 & 5179 (Washington, D.C.) \\
1992 & 4998 (Chicago) \\
1993 & 5635 (Washington, D.C.) \\
1994 & 5902 (New York) \\
1995 & 5559 (Chicago) \\
1996 & 6055 (San Francisco) \\
\hline & \\
\hline 19 &
\end{tabular}

Note: 1972-96 figures include exhibitors registered at the meeting, since their fee for booth rental includes the cost of their registration.

cluding breakfast roundtables, experimental panel formats, and a live broadcast of the Democratic National Convention. Hyde Park sessions, designed to broaden interaction between panel and audience, attracted considerable interest as well.

This year marked the first time that extensive poster sessions were included in the Annual Meeting and 290 posters were presented in three sessions. These sessions have expanded the number of people who can participate in the Annual Meeting and offer a format different from the usual panel presentations. We have learned that these sessions require more lighting than is normally available in hotels, though this problem may be beyond our control. In 
addition, there is an increasing demand for electronic equipment and electrical connections for poster presentations that we are struggling to meet. APSA's web site includes information on how to mount an effective poster presentation so that 1997 Annual Meeting participants can learn from the 1996 poster pioneers.

We also experimented with not reading the citations at the awards ceremony in order to have sufficient time for Arend Lijphart's Presidential Address. While most seasoned observers appreciated the effort to have the president speak at a reasonable hour, the consensus was that some short statement should be made about the reasons for granting each award, as the program chairs will do at the upcoming 1997 meeting in Washington, D.C. The recipients of all of the dissertation awards, except the Schattschneider, were likely pleased to see that, thanks to the generosity of APSA members and capital appreciation of our investments, the dissertation prizes had doubled to $\$ 500$.

Helping APSA make policy for its conference is the Annual Meeting Committee skillfully led by Mary Katzenstein. This newly created committee provides continuity and review of policies relating to the Annual Meeting, and it is this group that recommended APSA's successful foray into centralizing the processing of Annual Meeting proposals. Rather than sending multiple proposals to several of the 46 division chairs, members now submit their proposals, not to exceed two, to the national office. We sort through all 5,000 proposals, acknowledge them, distribute them to the appropriate members of the Program Committee, and let each division chair know what other division chair has received the same proposal. The process is thereby greatly rationalized and simplified both for proposers and committee members.

This new process facilitates more accurate record keeping concerning acceptance rates. What we discovered in our preliminary analysis this spring, for example, was that more people are being accommodated on the program than we had originally thought with approximately $40 \%$ of the proposals and $60 \%$ of the people who apply finding a place on the Annual Meeting Program. It should be noted, however, that these rates vary considerably across divisions.

Despite a few concerns expressed by graduate students, this new process had no apparent impact on graduate student participation, approximately 600 graduate students serving on panels in the upcoming Washington meeting. Nevertheless, the Annual Meeting Committee is working to create a norm that graduate students who are nearing completion of their graduate programs are more appropriate candidates to deliver papers at the Annual Meeting than are their junior colleagues and that only in exceptional circumstances should graduate students serve as panel chairs or discussants.

Through the years APSA has strived to make the Annual Meeting a welcome place for graduate students with features like inexpensive preregistration for the meeting, almost-free child care services, a roommate matching service offered at no cost, a free placement service, a leading scholar workshop and breakfasts, a grand reception for graduate students hosted by the President and President-Elect, and dissertation awards for the best dissertations in eight broadly defined fields of political science.

\section{Committees on Departmental Services and on Education and Professional Development}

We have also worked to encourage the participation of high school teachers and community college scholars with special rates at the meeting and with the Council's new policy of providing memberships for people in these categories at an inviting $\$ 30$. The current chair of the Departmental Services Committee (DSC), Tom Richards of Brookdale Community College in New Jersey, and the chair of the Committee on Education and Professional Development (CEPD), Richard Niemi of the University of Rochester, have effectively led the Association in these and other efforts to be more inclu- sive of colleagues from a broader range of institutions.

These committees have also overseen a number of successful APSA projects this year, including most of the directories and the surveys (DSC); newsletters and workshops for chairs of departments of political science (DSC); the Small Research Grant Program (CEPD in concert with the Research Support Advisory Board); departmental services for graduate, four-year, two-year, and high school programs (DSC); the monthly Personnel Service Newsletter (DSC); the programs on civic education for scholars and teachers from Eastern Europe and Russia (CEPD); recognition for political scientists who have won campus-wide teaching awards (CEPD); Annual Meeting panels and a special poster session on teaching (CEPD); and other activities.

\section{Research Support Advisory Board}

In addition to assisting in the selection of the Small Research Grant recipients, the Research Support Advisory Board ably led by Herb Asher of Ohio State University, is settling into its new role established in APSA's reorganization last year of receiving information about APSA's representational activities. APSA joins with other organizations in this work, and we have met with success in this coalitional approach thus far. For example, APSA has been working through the Consortium of Social Science Associations and the Coalition for National Science Funding, both directed with considerable ability by political scientist Howard Silver, to increase the research funding for the National Science Foundation. While appropriations have not been completed yet, on July 16 the House approved a healthy $6.6 \%$ increase in spending for NSF. This result is especially remarkable in the wake of the balanced budget agreement that calls for large real decreases in the discretionary part of the federal budget where NSF resides. Unfortunately, $\$ 174,000$ was removed on the House floor to express members' distaste for a peer- 
reviewed, funded study by the political science program.

APSA has also been working through the National Humanities Alliance to support the National Endowment for the Humanities (NEH), again with success. After overwhelmingly defeating an amendment to eliminate funding for the agency, on July 15 the House passed the Interior appropriations bill which includes $\$ 110$ million in funding for $\mathrm{NEH}$. This is a major victory for an organization slated for elimination two years ago.

NEH's sister agency, the National Endowment for the Arts, was provided no funding by the House, but is faring better in the Senate where the appropriations subcommittee for these agencies has approved $\$ 100$ million for NEA and $\$ 110$ for NEH. The same subcommittee also resussitated the Woodrow Wilson International Center for Scholars, which had been savaged by the House, by providing for funding at the same level as last year. How the House and Senate will resolve their differences on these matters is unclear as of this writing. Obviously, much more work needs to be done before Congress finishes working its will, but our efforts are paying off.

In a third area, that of the National Archives and Records Administration (NARA), APSA has been afforded savvy and energetic representation by Martha Kumar of Towson State University who simultaneously represents us on the Board of the National Coordinating Committee for the Promotion of History (NCC). She is protecting our scholarly interests on many fronts-from making available the electronic records of the Nixon Administration to ensuring that NARA funds documentary records projects. Elsewhere in this issue of $P S$ you will find a summary of recommendations and findings of the Moynihan Commission on Protecting and Reducing Government Secrecy. Professor Kumar brought this report to the attention of APSA's Council who has recommended that APSA members review the recommendations and consider whether APSA should endorse this report.

\section{Electronic Publishing}

APSA's collaborations with other organizations extend far beyond our representational activities, as is evident from the highlights I listed earlier in this report. One area where partnership has been especially helpful has been in the field of electronic publishing, both policy and projects, which are thoughtfully overseen by Walter Stone of the University of Colorado and his Committee on Publications. We have made great advances on our web site, created by APSA's Webmaster Sean Twombly and supported by H-Net at Michigan State University. I hope that you will take a look at http://www.apsanet.org.

This site is deep, with many links to locations of interest to the political science community. It includes, among many other things, the entire Annual Meeting Preliminary Program and a considerable amount of material on civic education, thanks to Director of Education and Professional Development Sheilah Mann's untiring efforts to promote teaching in the profession and to secure grants for the Association. We have also set up a series of new discussion lists for Organized Sections, related groups in political science, APSA committees, and other groups like the core graduate schools of the Minority Identification Project.

The Mellon Foundation's JSTOR is up and running with all past issues of the APSR available electronically up to the year 1994. A series of other social science associations are participating in this project so that all of our journals can be searched in tandem across the disciplines. Be sure to check out the site at http:// www.jstor.org and then ask your library to join it if has not already done so. In a related vein, we have been investigating the best way to produce our journals from an electronic platform, both to take advantage of new technology and to start making current issues of our journals available on-line for APSA members.

Another place to look if you are interested in digital developments is in the "Profession" Section of this issue of PS. The document entitled "Basic Principles for Managing Intellectual Property in the Digital Envi-
TABLE 2

$$
\begin{aligned}
& \text { Organized Section } \\
& \text { Members, } 1997
\end{aligned}
$$

\begin{tabular}{|c|c|c|}
\hline & Organized Section & $\begin{array}{l}\text { Number of } \\
\text { Members* }\end{array}$ \\
\hline & $\begin{array}{l}\text { Federalism and } \\
\text { Intergovernmental } \\
\text { Relations }\end{array}$ & 370 \\
\hline 2 & Law and Courts & 718 \\
\hline 3 & Legislative Studies & 555 \\
\hline 4 & Public Policy & 748 \\
\hline 5 & $\begin{array}{l}\text { Political Organizations } \\
\text { and Parties }\end{array}$ & 504 \\
\hline 6 & Public Administration & 590 \\
\hline 7 & Conflict Processes & 269 \\
\hline 8 & $\begin{array}{l}\text { Representation and } \\
\text { Electoral Systems }\end{array}$ & 307 \\
\hline 9 & Presidency Research & 381 \\
\hline 10 & Political Methodology & 553 \\
\hline 11 & Religion and Politics & 387 \\
\hline 13 & Urban Politics & 394 \\
\hline 15 & $\begin{array}{l}\text { Science, Technology, } \\
\text { and Environmental } \\
\text { Policy }\end{array}$ & 315 \\
\hline 16 & Women and Politics & 526 \\
\hline 17 & $\begin{array}{l}\text { Foundations of Political } \\
\text { Theory }\end{array}$ & 518 \\
\hline 18 & $\begin{array}{l}\text { Computers and } \\
\text { Multimedia }\end{array}$ & 238 \\
\hline 19 & $\begin{array}{l}\text { International Security } \\
\text { and Arms Control }\end{array}$ & 433 \\
\hline 20 & Comparative Politics & 1389 \\
\hline 21 & $\begin{array}{l}\text { Politics and Society in } \\
\text { Western Europe }\end{array}$ & 376 \\
\hline 22 & State Politics and Policy & 352 \\
\hline 23 & Political Communication & 376 \\
\hline 24 & Politics and History & 560 \\
\hline 25 & Political Economy & 589 \\
\hline 26 & Transformational Politics & 249 \\
\hline 27 & New Political Science & 244 \\
\hline 28 & Political Psychology & 286 \\
\hline 29 & $\begin{array}{l}\text { Undergraduate } \\
\text { Education }\end{array}$ & 297 \\
\hline 30 & Politics and Literature & 258 \\
\hline 31 & $\begin{array}{l}\text { Public Opinion and } \\
\text { Foreign Policy }\end{array}$ & 289 \\
\hline 32 & $\begin{array}{l}\text { Elections, Public } \\
\text { Opinion, and Voting } \\
\text { Behavior }\end{array}$ & 614 \\
\hline 33 & Race, Ethnicity \& Politics & 418 \\
\hline
\end{tabular}

*As of May 21, 1997

ronment," prepared by the National Humanities Alliance and endorsed by APSA's Council, recognizes the need to balance the objectives of fair use and protection of intellectual property rights for materials distrib- 
TABLE 3

APSA Members 1974-1996

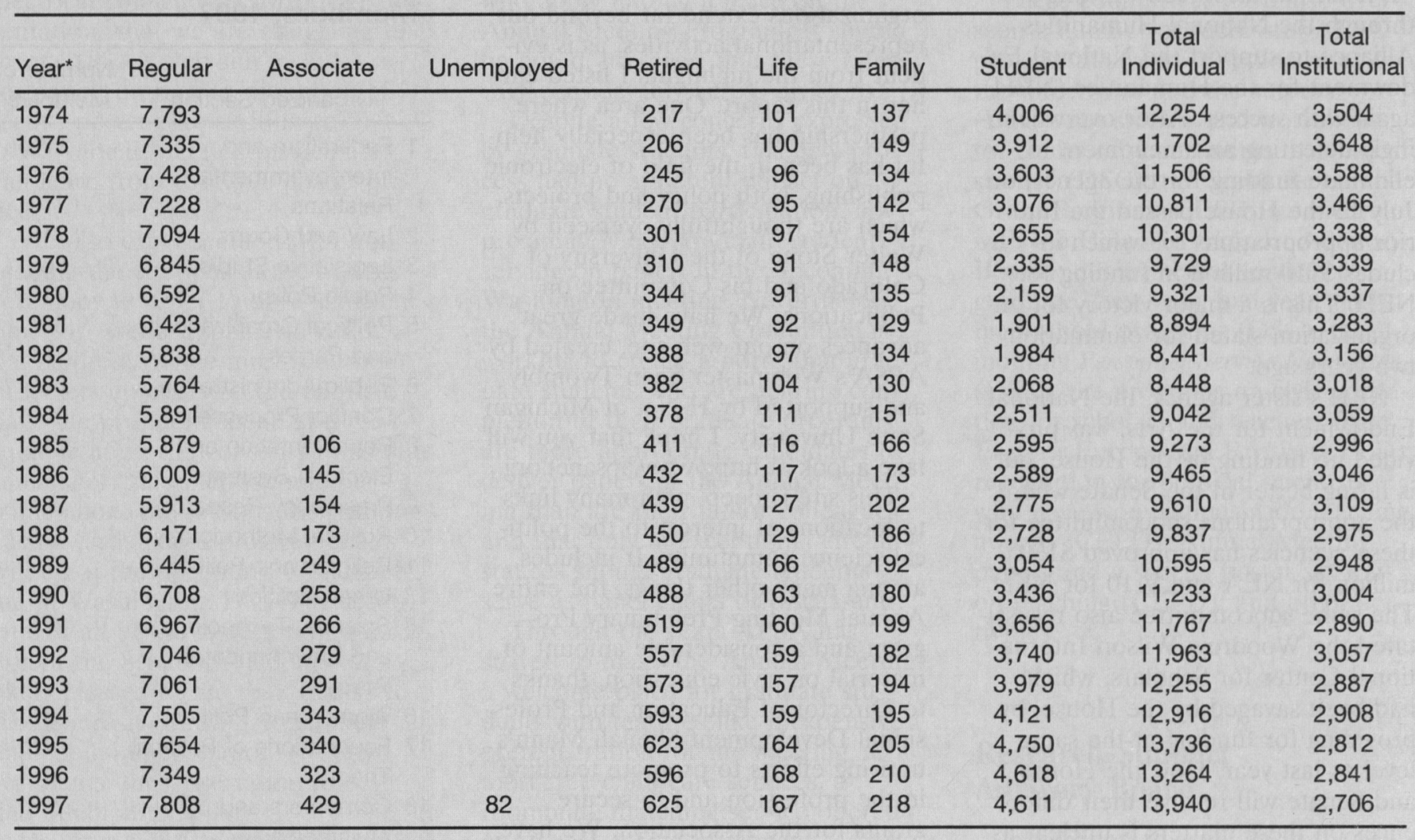

${ }^{\star}$ As of January 15 each year.

uted digitally. The ten principles explicated in the report are well worth reviewing and will set APSA's agenda in upcoming battles on Capitol Hill concerning intellectual property rights.

In concert with the Harvard University Library, we have been exploring the possibility of making Annual Meeting papers available on-line. Thanks to the prodigious efforts of William J. Ball, and the magnanimous spirit of Sidney Verba and his Harvard Library staff, a pilot project is underway to supply 300 papers electronically for the 1997 Annual Meeting. Program Chairs James Alt of Harvard University and Margaret Levi of the University of Washington have been especially supportive of these efforts led by Professor Ball.

\section{International Programs}

Of course, one of the advantages of electronic provision is that APSA can more easily make its materials available worldwide. Imagine if universities in the newly emerging democracies could, in one fell swoop, have access to the entire corpus of APSR. This possibility is quite plausible. In the meantime, APSA is donating current issues of APSR and $P S$ to scores of universities in central and eastern Europe and in Sub-Saharan Africa. We are also encouraging scholars who are retiring and who would like to give away their collections of journals to work through the East and Central European Journal Donation Project, by contacting Claudia Bedrick at the New School for Social Research (212-229-5586), or through Bridge to Asia (http://www.bridge.com/books .html or 510-834-3082).

These donation programs are overseen by the Committee on International Programs whose vigorous new chair is Richard Merritt of the University of Illinois. Under Professor Merritt's leadership APSA has concluded an agreement with the
Political Studies Association of the United Kingdom to engage in collaborative activities, the first of which is the listing of British institutions in next year's Guide to Graduate Faculty and Programs, approved earlier by the Departmental Services Committee. This new arrangement follows on the heels of the successful exchange that APSA has had with the Japanese Political Science Association (JPSA) for the past seven years. In 1996, Herbert Weisberg of Ohio State University and Clyde Wilcox of Georgetown University represented APSA at the JPSA Annual Meeting in Sapporo. M. Kent Jennings of the University of California-Santa Barbara and Peter Katzenstein, Cornell University, will represent the Association at the 1997 JPSA meeting in Tokyo.

Another initiative of this committee is a developing program of cooperation with Ukranian political scientists. The first step will be a visit from a Ukranian political scientist 
TABLE 4

Budget Summary, FY 1983-1997

\begin{tabular}{crrr}
\hline Year & \multicolumn{1}{c}{ Income } & Expenditures & Surplus \\
\hline $1982-83$ & $\$ 1,202,078$ & $\$ 1,094,415$ & $\$ 107,653$ \\
$1983-84$ & $1,323,074$ & $1,247,529$ & 75,545 \\
$1984-85$ & $1,415,077$ & $1,353,334$ & 54,738 \\
$1985-86$ & $1,505,224$ & $1,453,248$ & 51,976 \\
$1986-87$ & $1,585,000$ & $1,500,000$ & 85,307 \\
$1987-88$ & $1,637,637$ & $1,563,252$ & 74,385 \\
$1988-89$ & $1,847,151$ & $1,731,248$ & 115,903 \\
$1989-90$ & $1,891,773$ & $1,871,302$ & 20,471 \\
$1990-91$ & $2,158,118$ & $2,133,524$ & 24,594 \\
$1991-92$ & $2,256,647$ & $2,199,632$ & 74,804 \\
$1992-93$ & $2,290,313$ & $2,202,419$ & 87,894 \\
$1993-94$ & $2,574,436$ & $2,294,128$ & 280,308 \\
$1994-95$ & $2,734,375$ & $2,524,663$ & 209,712 \\
$1995-96$ & $2,822,154$ & $2,590,227$ & 231,927 \\
$1996-97^{\star}$ & $2,979,845$ & $2,793,237$ & 186,607 \\
\hline
\end{tabular}

*Projected.
TABLE 5

Market Value of APSA

Funds, 1984-97

\begin{tabular}{ccc}
\hline Year* & $\begin{array}{c}\text { Trust and } \\
\text { Development } \\
\text { Fund }\end{array}$ & $\begin{array}{c}\text { Endowed } \\
\text { Programs } \\
\text { Funds }\end{array}$ \\
\hline 1984 & $1,001,775$ & 225,580 \\
1985 & $1,450,032$ & 264,149 \\
1986 & $1,677,365$ & 304,105 \\
1987 & $1,811,794$ & 362,174 \\
1988 & $1,685,345$ & 382,268 \\
1989 & $1,643,552$ & 394,837 \\
1990 & $1,630,718$ & 419,021 \\
$1991 \dagger$ & $1,555,574$ & $5,452,252$ \\
1992 & $1,905,090$ & $6,188,105$ \\
1993 & $2,118,787$ & $6,847,760$ \\
1994 & $2,190,976$ & $7,218,462$ \\
1995 & $2,807,182$ & $7,774,290$ \\
1996 & $3,248,013$ & $9,442,658$ \\
1997 & $3,682,016$ & $9,696,773$ \\
(projected) & \\
\hline
\end{tabular}

*June 30 of each year.

†Figures for 1991-1993 have been restated to reflect current accounting practice. The apparent drop in T \& D market value in 1991 is due only to this reallocation across funds and does not represent a true decrease in value.

\section{Centennial Campaign}

It should be abundantly clear that APSA's committees and staff spend much time thinking ahead and planning for the future, not only for a future World Congress but also in a hundred other ways. This planning pays off for the profession, sometimes monetarily-like room rates in Boston of \$93 in 1998-but more often in less-tangible ways that benefit the profession. I think that the JSTOR project is a good example.

An emerging illustration is the coming Centennial Campaign which will be launched formally at the 1998 Annual Meeting but which is already well underway and destined to be very successful. I am especially sanguine about our prospects to raise $\$ 1$ million for future generations of political scientists because of the extraordinary leadership that has come forward to take up the challenge to make sure that the next century of political science is as productive as the last.

I am deeply gratified to announce the leaders of the Campaign. Dale
Rogers Marshall, President of Wheaton College in Massachusetts, and Jack Peltason, former President of the University of California, have gladly agreed to co-chair this effort. Co-chairing the Executive Committee are Frank Sorauf of the Universon of the University of Maryland. The Chairs of the Presidents Council are Lucius Barker of Stanford University and Elinor Ostrom of Indiana University. The Finance Co-chairs are Susan Bourque of Smith College and Loren Ross of Cedarpoint Capital Management of New York.

These leaders are offering their judgment, energy, time, money, and leadership to the Campaign. They have recruited a stellar Executive Committee and Presidents Council, whose composition we will be announcing shortly, and all have agreed to become major contributors to the Campaign.

The Centennial Campaign gives all of us an opportunity to ensure sity of Minnesota and Roger David- 


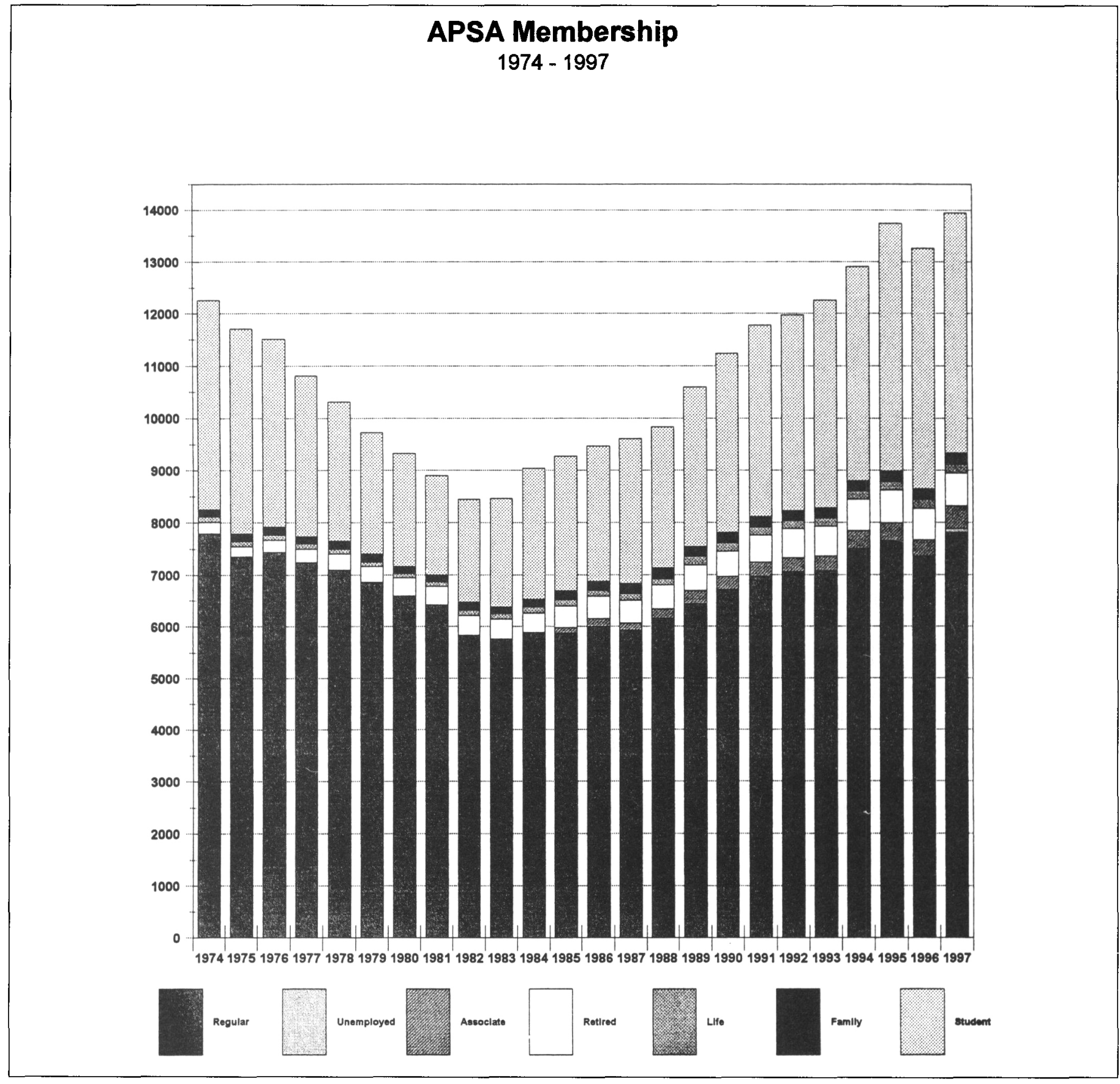

opportunities for those who come after us. We have been blessed with relative prosperity in recent generations, and we can endow opportunities for those who follow.

\section{Vital Signs}

As proof of our good fortune in this century, as an organization and as a discipline, the tables dotting this report should prove instructive. Organized Sections are thriving (Table 2), membership is robust (Table 3 and Figure 1), our budget is in the black (Table 4), and our investments are growing (Table 5). The source of this good fortune stems from the support, work, and dedication of the members of this remarkable Association.

\section{Denouement}

For a full review of the activities reported here and others too numerous to include, see the articles in $P S$ over the past year listed in the addendum. In addition to the Council, 19 substantive committees, two editorial boards, 21 award committees, and 11 representatives to other organizations with which we are affiliated carry out the work of APSA, only some of which I could highlight here.

Throughout my report I mention APSR, conscientiously and intelligently edited by Ada Finifter of Michigan State University, and PS: 
Political Science and Politics, imaginatively edited by APSA Deputy Director Robert Hauck. These two publications represent two of the most important products of APSA. Like clockwork, every quarter you find these publications in shrinkwrap on your doorstep. It is easy to take them for granted, but both of these publications are labors of love not only of the editors but of their staffs and reviewers. There is nothing new to say about either journal because of their consistency, but it is worth eflecting on the fact that we have such superb resources at our fingertips.

You might also want to peruse the following list of Association leaders and staff who work vigorously for APSA and who are anxious to hear from you, as I am, as you have ideas for this Association.
APSA Officers

PRESIDENT

Elinor Ostrom, Indiana University

\section{PRESIDENT-ELECT}

M. Kent Jennings, U. of California, Santa Barbara

\section{VICE PRESIDENTS}

Suzanne Berger, Massachusetts Institute of Technology

William E. Nelson, Jr., Ohio State University

G. Bingham Powell, Jr., University of Rochester

TREASURER

Gary C. Jacobson, University of California, San Diego

\section{SECRETARY}

Virginia Sapiro, University of Wisconsin-Madison

\section{EXECTIVE DIRECTOR}

Catherine E. Rudder

MANAGING EDITOR, APSR

Ada Finifter, Michigan State University

\section{COUNCIL}

1995-97

Ruth Collier, University of California, Berkeley

Michael W. Giles, Emory University

Rodney E. Hero, University of Colorado, Boulder

Pamela K. Jensen, Kenyon College

Bruce W. Jentleson, University of California, Davis

Richard Payne, Illinois State University

Ian Shapiro, Yale University

Paul Sniderman, Stanford University

\section{6-98}

Ackelsberg, Smith College

E.J. Dionne, The Washington Post

Kathie Stromile Golden, Morris Brown College

John E. Jackson, University of Michigan

David Laitin, University of Chicago

Michael Laver, Trinity College-Dublin, Ireland

John G. Ruggie, United Nations

John Stewart, Jr., University of New Mexico
(202)483-2512

(617)495-2184

(206)543-7947

(517)355-3400

Telephone

Numbers

(812)855-3151

(805)893-4260

(617)253-6640

(614)292-0453

(716)275-0621

(619)534-4295

(608)263-1793

(510)643-8019

(404)727-6565

(303)492-7585

(614)427-5308

(202)296-8221

(309)438-5393

(203)432-5253

(415)723-1806

(413)585-3533

(202)334-6707

(404)220-0292

(313)763-3080

(312)702-0522

353-1-608-2036

(212) 963-9082

(505)277-5104
E-mail Addresses

ostrom@indiana.edu

jennings@alishaw.ucsb.edu

szberger@mit.edu

nelson.18@osu.edu

bpow@troi.cc.rochester.edu

gjacobso@weber.ucsd.edu

sapiro@polisci.wisc.edu

rudder@apsanet.org

jalt@latte.harvard.edu mlevi@u.washington.edu

finifter@msu.edu

rcollier@socrates.berkeley.edu mgiles@social-sci.ss.emory.edu hero@osiris.colorado.edu jensen@kenyon.edu bwjentleson@ucdavis.edu rjpayne@rss.6000.cmp.ilstu.edu ianshap@minerva.cis.yale.edu

mackelsb@sophia.smith.edu adionne@brook.edu kgolden@morrisbrown.edu jjackson@healey.bus.umich.edu lait@cicero.spc.uchicago.edu malver@tcd.ie ruggie@un.org joestew@unm.edu 
STANDING COMMITTEE CHAIRS

\section{Nominating Committee}

Tracy B. Strong, University of CA, San Diego

(619)534-7081

Trust and Development Board of Trustees

Gary C. Jacobson, Treasurer

(619)534-4295

(908)224-2261

Committee on Departmental Services

Tom Richards, Brookdale Community College

Committee on Publications

Walter J. Stone, University of Colorado at Boulder

(303)492-2363

\section{Committee on Education}

Richard Niemi, Rochester University

(715)275-5364

(217)344-4573

(617)552-4174

(614)292-0803

$(504) 771-3210$

Committee on the State of Blacks in the
Edward R. Jackson, Southern University

Committee on the Status of Latinos in the Profession

Benjamin Marquez, University of Wisconsin, Madison

(608)263-2414

(315)443-2416

Kristi Anderson, Syracuse University

\section{Endowed Programs Committee}

Linda Fowler, Dartmouth College

$(603) 646-3874$

Committee on the Status of Lesbians and Gays in the Profession

Harry Hirsch, University of California, San Diego

(619)822-0525

(913)864-9098

(415)723-0672

Editorial Board, PS

Richard Brody, Stanford University

\section{CENTENNIAL CAMPAIGN}

\section{Co-Chairs}

Dale Rogers Marshall, Wheaton College

Jack Peltason, University of California

\section{Executive Committee Co-Chairs}

Frank Sorauf, University of Minnesota

Roger Davidson, University of Maryland

\section{Presidents Council Co-chairs}

Lucius Barker, Stanford University

Elinor Ostrom, Indiana University
(508)285-8244

(714)824-3938

(612)624-5503

(301)405-4113

(415)723-0408

(812)855-3151 tstrong@weber.ucsd.edu

gjacobso@weber.ucsd.edu

walter.stone@colorado.edu

pscl@troi.cc.rochester.edu

richmerr@uiuc.edu

kschloz@bcvms.bc.edu

asker.1@osu.edu

marquez@polisci.wisc.edu

linda.fowler@dartmouth.edu

hhirsch@ucsd.edu

b-romzek@ukans.edu

brody@leland.stanford.edu

dmarshall@wheatonma.edu newbean@aol.com

sorauf@polisci.umn.edu rdavidso@bss2.umd.edu

ostrom@indiana.edu 
Finance Co-Chairs

Susan Bourque, Smith College

Loren Ross, Cedarpoint Capital Management of New York

Minority Identification Project Steering Committee

Elliott Slotnick, Ohio State University

Congressional Fellowship Program Advisory Committee

Norman Ornstein, American Enterprise Institute for Public Policy

(202)862-5893

\section{APSA Political Science Staff}

Robert J-P. Hauck, Deputy Director

Sheilah Mann, Director of Educational Programs

Maurice Woodard, Director of Minority Affairs

Jun Yin, Staff Associate
(413)585-3000

(212)308-9081

(614)292-2880

slotnick.|@osu.edu

loren@rsage.edu sbourque@smith.smith.edu

rhauck@apsanet.org smann@apsanet.org woodard@apsanet.org jyin@apsanet.org

richards@apsanet.org

\section{Contributors to APSA Awards and Programs}

\author{
E. Obiri Addo \\ Anthony Desales Affinge \\ William I. Bacchus \\ Robert $\mathrm{H}$. Bates \\ Frederic A. Bergerson \\ Wallace H. Best \\ Henry E. Brady \\ Richard Brody \\ James MacGregor Burns \\ Elizabeth Capell \\ David L. Coleman \\ Roger H. Davidson \\ David W. Davis \\ Leon D. Epstein \\ John G. Eriksen \\ Kichizo Fujimoto \\ Jose E. Garriga-Pico \\ Michael Jaye Gilbreath \\ Vanna Gonzales \\ Glen Halva-Neubbauer \\ Leslie I. Hill \\ Jennifer L. Hochschild
}

Mathhew Holden, Jr. Karen M. Holt

Charlotte Joseph

Loch K. Johnson

Robin A. Kolodny

Logan A. Lee

Arthur J. Lerman

Phoebe S. Liebig

Arend Lijphart

Burdett A. Loonns

Claude Marx

Karen M, McCurdy

Wilson Carey McWilliams

William D. Muller

Patrick A. Mulloy

Akiko Ohara

Leonard Parkinson

Anne M. Parsons

Pamela D. Pelletreau

Jack W. Peltason

Edward J. Pfeiffer

Daniel R. Popkey
Francis E. Rourke

Catherine Rudder

Wilma Rule

Kay Lehman Schlozman

George C. Shipley

Howard J. Silver

Harold W. Stanley

John G. Stewart

Donald Tannenbaum

Edward Thompson III

David B. Truman

David M. Wilson

James $Q$. Wilson

Kazuo Yamauchi

Thank You!

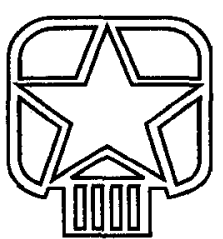

